\title{
Penggunaan Metode Elimination ET Choix Traduisant LA Realite (ELECTRE) Untuk Menentukan Penerima Beasiswa PPA
}

\author{
M. Ary Pratama*¹, Volvo Sihombing ${ }^{2}$, Deci Irmayani ${ }^{3}$ \\ ${ }^{1,2,3}$ Fakultas Sains dan Teknologi, Universitas Labuhanbatu \\ e-mail: *11arybigbos@gmail.com, ${ }^{2}$ volvolumbantoruan@ gmail.com, \\ 3deacyirmayani@gmail.com
}

\begin{abstract}
Abstrak
Penelitian ini bertujuan untuk membantu pihak Fakultas Sains dan Teknologi Universitas Labuhanbatu dalam pengambilan keputusan penentuan kelayakan mahasiswa untuk menerima beasiswa peningkatan prestasi akademik. Penentuan penerimaan beasiswa ini dilakukan dengan membangun sebuah sistem pendukung keputusan yang membantu mempermudah dalam menentukan mahasiswa yang berhak untuk mendapatkan beasiswa tersebut. Sistem pendukung keputusan yang dibangun menggunakan metode Electre. Kriteria yang digunakan dalam SPK Metode Electre ini terdiri dari indeks prestasi mahasiswa, penghasilan orang tua, jumlah tanggungan orang tua, jumlah sertifikat prestasi. Masingmasing kriteria diberi bobot dengan perbandingan 5, 2, 2, 1. Hasil akhir dari SPK metode Electre ini adalah rekomendasi melalui data rangking yang ditentukan berdasarkan jumlah angka 1 terbanyak. Hasil dari studi kasus dalam penelitian ini, diperoleh alternatif dengan nilai 1 terbanyak didapatkan oleh alternatif Mhs_007, dan alternatif dengan nilai 1 paling sedikit dapat dieleminasi.
\end{abstract}

Kata kunci- Beasiswa, Penentuan, Kriteria, SPK, Electre, Ranking

\begin{abstract}
This study aims to assist the Faculty of Science and Technology, Labuhanbatu University in making decisions to determine student eligibility to receive scholarships to increase academic achievement. Determining the acceptance of this scholarship is done by building a decision support system that helps make it easier to determine which students are eligible for the scholarship. A decision support system built using the Electre method. The criteria used in the SPK Electre Method consist of student achievement index, parents' income, number of dependents of parents, number of achievement certificates. Each criterion is given a weight with a ratio of 5, 2, 2, 1. The final result of the SPK Electre method is a recommendation through ranking data determined based on the highest number of numbers 1. The results of the case study in this research show that the alternative with the most value of 1 is obtained by the Mhs_007 alternative, and the alternative with the least value of 1 can be eliminated.
\end{abstract}

Keywords - Scholarship, Determination, Criteria, DSS, Electre, Ranking 


\section{PENDAHULUAN}

$\mathrm{U}$ ntuk merangsang peningkatan prestasi belajar mahasiswa, salah satu cara yang sudah lama dilakukan oleh pihak pendidik adalah dengan memberikan kompensasi berupa beasiswa belajar bagi mahasiswa yang berprestasi. Dengan mengetahui prestasi belajar mahasiswa, perguruan tinggi dapat melakukan evaluasi apakah metode pengajaran yang digunakan telah berhasil diterima dengan baik atau tidak oleh mahasiswa yang diajar.

Demikian halnya di Fakultas Sains dan Teknologi Universitas Labuhanbatu, juga terdapat program pemberian beasiswa bagi mahasiswa/i yang salah satunya adalah beasiswa peningkatan prestasi akademik. Tujuan dari beasiswa peningkatan prestasi akademik ini adalah untuk merangsang dan memfasilitasi mahasiswa dalam peningkatan prestasi nya di bidang akademik.

Permasalahan yang sering dihadapi pihak kampus dalam pemberian beasiswa kepada mahasiswa adalah memilih mahasiswa penerima beasiswa yang tepat, sehingga beasiswa yang diberikan tepat sasaran. Beasiswa harus diberikan kepada mahasiswa/i penerima yang layak dan pantas untuk mendapatkannya. Agar menghasilkan keputusan yang tepat maka seleksi penerimaan beasiswa ini harus menerapkan aturan-aturan yang telah ditetapkan. Untuk mengatasi masalah penentuan layak atau tidaknya mahasiswa dalam menerima beasiswa tersebut, dapat digunakan sistem pendukung keputusan untuk lebih memudahkan dalam penyeleksian mahasiswa penerima beasiswa [1]-[4], [5].

Saat ini penggunaan sistem pendukung keputusan sudah banyak digunakan untuk membantu dalam mengambil keputusan baik di bidang pendidikan [6], [7]-[9], bidang ekonomi [10], bidang pekerjaan umum [11]-[14] dan bidang-bidang lainnya [15]-[17], [18]-[21].

Oleh karena itu, dirancang sebuah Sistem pendukung keputusan untuk membantu pihak kampus dalam menentukan siapa yang berhak dalam mendapatkan beasiswa di Fakultas Sains dan Teknologi Universitas Labuhanbatu. Sistem pendukung keputusan ini dirancang dengan menggunakan metode Elimination Et Choix Traduisant La Realite (ELECTRE) sehingga mempermudah pihak fakultas dalam menentukan mahasiwa yang tepat untuk menerima beasiswa peningkatan prestasi akademik. Dengan menggunakan metode Electre ini pihak pemberi beasiswa dapat lebih mempermudah dalam melakukan eliminasi terhadap calon penerima beasiswa yang tidak memenuhi syarat [22]-[24], [25].

\section{METODE PENELITIAN}

Langkah-langkah yang dilakukan dalam membangun sistem pendukung keputusan dengan menggunakan metode Electre ini dapat dilihat pada gambar 1.

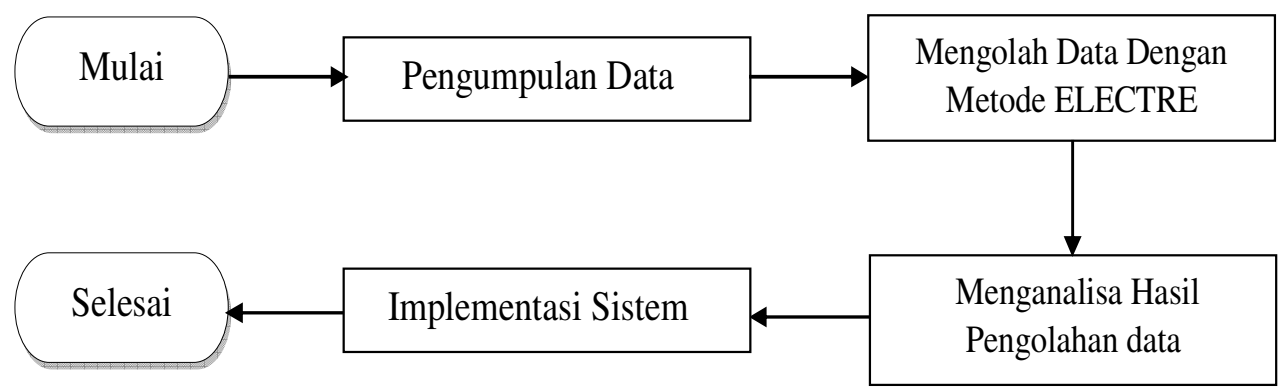

Gambar 1. Flowchart Penelitian

Pratama, et., al [Penggunaan Metode Elimination ET Choix Traduisant La Realite (ELECTRE) Untuk Menentukan Penerima Beasiswa PPA] 
Tahapan penelitian yang dilakukan dimulai dari pengumpulan data dari alternatifalternatif yang akan diolah. Data yang dikumpulkan merupakan data mahasiswa Program Studi D3 Manajemen Informatika Universitas Labuhanbatu. Data yang dikumpulkan terdiri dari data Nilai Semester (C1), Penghasilan Orang Tua (C2), Jumlah Tanggungan Orang Tua (C3), dan Jumlah Sertifikat Prestasi (C4).

Data Nilai IP Semester berguna untuk mengukur prestasi akademik mahasiswa. Semakin tinggi prestasi akademik dari mahasiswa maka peluang untuk mendapatkan beasiswa semakin besar. Data penghasilan orangtua digunakan untuk mengukur tingkat penghasilan orangtua untuk mendapatkan beasiswa. Jika tingkat penghasilan orangtua semakin rendah maka peluangnya mendapat beasiswa akan semakin besar. Data jumlah tanggungan orang digunakan untuk mengukur beban tanggungan orangtua dari mahasiswa untuk mendapatkan beasiswa. Semakin banyak tanggungan dari orangtua mahasiswa yang mendaftar maka peluangnya mendapatkan beasiswa akan semakin besar. Nilai test yang digunakan akan nilai test wawancara yang dilaksanakan bagi setiap alternatif mahasiswa.

Data alternatif yang akan diolah dalam SPK penerima beasiswa ini dapat dilihat pada tabel 1.

Tabel 1. Perbandingan Algoritma A dan Algoritma B

\begin{tabular}{|c|l|c|c|c|c|}
\hline Alternatif & $\begin{array}{l}\text { Nama } \\
\text { Mahasiswa }\end{array}$ & IP & $\begin{array}{l}\text { Penghasilan } \\
\text { Orang Tua }\end{array}$ & $\begin{array}{l}\text { Jumlah } \\
\text { Tanggungan } \\
\text { Orang Tua }\end{array}$ & $\begin{array}{l}\text { Sertifikat } \\
\text { Prestasi }\end{array}$ \\
\hline A01 & Mhs_001 & 3.62 & 3.575 .000 & 1 & 4 \\
\hline A02 & Mhs_002 & 3.14 & 2.786 .000 & 3 & 2 \\
\hline A03 & Mhs_003 & 3.32 & 2.524 .000 & 3 & 3 \\
\hline A04 & Mhs_004 & 3.2 & 3.13 .000 & 4 & 3 \\
\hline A05 & Mhs_005 & 3.51 & 4.542 .000 & 2 & 3 \\
\hline A06 & Mhs_006 & 3.62 & 2.515 .000 & 3 & 1 \\
\hline A07 & Mhs_007 & 3.53 & 5.550 .000 & 3 & 5 \\
\hline A08 & Mhs_008 & 3.22 & 2.535 .000 & 3 & 4 \\
\hline A09 & Mhs_009 & 3.37 & 3.500 .000 & 4 & 5 \\
\hline A10 & Mhs_010 & 3.63 & 2.585 .000 & 4 & 1 \\
\hline
\end{tabular}

Tahap selanjutnya, data tersebut diolah dengan menggunakan metode Electre dan bobot yang digunakan untuk setiap kriteria dapat dilihat pada tabel 2 .

Tabel 2. Kriteria dan Nilai Untuk Setiap Kriteria

\begin{tabular}{|c|c|c|c|}
\hline \multicolumn{2}{|c|}{ Kriteria } & \multicolumn{2}{c|}{ Nilai Skala } \\
\hline Variabel & Keterangan & Skala & Nilai \\
\hline \multirow{4}{*}{ C1 } & & $>3.5$ & 5 \\
& \multirow{3}{*}{ IP } & $3.01-3.4$ & 4 \\
& & $2.8-3.0$ & 3 \\
& & $2.5-2.79$ & 2 \\
\multirow{2}{*}{ C2 } & Jumlah & $>2.5$ & 1 \\
& penghasilan & $4.000 .000-5.000 .000$ & 2 \\
\hline
\end{tabular}

Pratama, et., al [Penggunaan Metode Elimination ET Choix Traduisant La Realite (ELECTRE) Untuk Menentukan Penerima Beasiswa PPA] 


\begin{tabular}{|c|c|c|c|}
\hline & orangtua & $3.000 .000-3.999 .999$ & 3 \\
& & $2.500 .00-2.999 .999$ & 4 \\
& & $<2.500 .00$ & 5 \\
\hline \multirow{4}{*}{ C3 } & \multirow{3}{*}{ Jumlah } & $>5$ orang & 5 \\
& tanggungan & 4 orang & 4 \\
& orangtua & 3 orang & 3 \\
& & 2 orang & 2 \\
& & 1 orang & 1 \\
\hline \multirow{3}{*}{ C4 } & Sertifikat & $>=5$ & 5 \\
& Prestasi & 4 & 4 \\
& & 3 & 3 \\
& & 2 & 2 \\
\hline
\end{tabular}

\section{HASIL DAN PEMBAHASAN}

Selanjutnya dilakukan analisa terhadap hasil pengolahan data dengan menggunakan metode Electre, sehingga dapat diambil kesimpulan mahasiswa yang paling tepat untuk memperoleh beasiswa peningkatan prestasi akademik. Tabel Rating kecocokan dari setiap kriteria alternatif pada setiap kriteria yang akan dianalisa dalam penelitian ini dapat dilihat pada tabel 3.

Tabel 3. Kriteria dan Nilai Untuk Setiap Kriteria

\begin{tabular}{|c|c|c|c|c|}
\hline \multirow{2}{*}{ Alternatif } & \multicolumn{5}{|c|}{ Kriteria } \\
\cline { 2 - 5 } & $\mathrm{C} 1$ & $\mathrm{C} 2$ & $\mathrm{C} 3$ & $\mathrm{C} 4$ \\
\hline $\mathrm{A} 01$ & 5 & 3 & 1 & 4 \\
\hline $\mathrm{A} 02$ & 4 & 4 & 3 & 2 \\
\hline $\mathrm{A} 03$ & 4 & 4 & 3 & 3 \\
\hline $\mathrm{A} 04$ & 4 & 3 & 4 & 3 \\
\hline $\mathrm{A} 05$ & 5 & 2 & 2 & 3 \\
\hline $\mathrm{A} 06$ & 5 & 4 & 3 & 1 \\
\hline $\mathrm{A} 07$ & 5 & 1 & 3 & 5 \\
\hline $\mathrm{A} 08$ & 4 & 4 & 3 & 4 \\
\hline $\mathrm{A} 09$ & 4 & 3 & 4 & 5 \\
\hline $\mathrm{A} 10$ & 5 & 4 & 4 & 1 \\
\hline
\end{tabular}

Dengan bobot masing-masing kriteria $\mathrm{W}=(5,2,2,1)$

Matrik keputusan yang dibentuk dari tabel kecocokan adalah sebagai berikut:

Pratama, et., al [Penggunaan Metode Elimination ET Choix Traduisant La Realite (ELECTRE) Untuk Menentukan Penerima Beasiswa PPA] 


$$
X=\left[\begin{array}{llll}
5 & 3 & 1 & 4 \\
4 & 4 & 3 & 2 \\
4 & 4 & 3 & 3 \\
4 & 3 & 4 & 3 \\
5 & 2 & 2 & 3 \\
5 & 4 & 3 & 1 \\
5 & 1 & 3 & 5 \\
4 & 4 & 3 & 4 \\
4 & 3 & 4 & 5 \\
5 & 4 & 4 & 1
\end{array}\right]
$$

Langkah- langkah penyelesaian :

1. Menentukan Normalisasi matriks

$$
\begin{aligned}
& \mathrm{R}_{11}=\frac{5}{5^{2}+4^{2}+4^{2}+4^{2}+5^{2}+5^{2}+5^{2}+4^{2}+4^{2}+5^{2}} \\
& =\frac{5}{\sqrt{14,3178}}=0,3492 \\
& \mathrm{R}_{12}=\frac{3}{3^{2}+4^{2}+4^{2}+3^{2}+2^{2}+4^{2}+1^{2}+4^{2}+3^{2}+4^{2}} \\
& =\frac{3}{\sqrt{10,5830}}=0,2825 \\
& \mathrm{R}_{13}=\frac{1}{1^{2}+3^{2}+3^{2}+4^{2}+2^{2}+3^{2}+3^{2}+3^{2}+4^{2}+4^{2}} \\
& =\frac{1}{\sqrt{9,8995}}=0,101 \\
& \mathrm{R}_{14}=\frac{4}{4^{2}+2^{2}+3^{2}+3^{2}+3^{2}+1^{2}+5^{2}+4^{2}+5^{2}+1^{2}} \\
& =\frac{4}{\sqrt{10,7238}}=0,3730 \\
& \mathrm{R}_{21}=\frac{4}{5^{2}+4^{2}+4^{2}+4^{2}+5^{2}+5^{2}+5^{2}+4^{2}+4^{2}+5^{2}} \\
& =\frac{4}{\sqrt{14}, 3178}=0,2794 \\
& \mathrm{R}_{22}=\frac{4}{3^{2}+4^{2}+4^{2}+3^{2}+2^{2}+4^{2}+1^{2}+4^{2}+3^{2}+4^{2}} \\
& =\frac{4}{\sqrt{10,5830}}=0,378
\end{aligned}
$$


Sehingga didapat matriks $\mathrm{R}$ hasil normalisasi

$$
R=\left[\begin{array}{cccc}
0,3492 & 0,2835 & 0,101 & 0,373 \\
0,2794 & 0,378 & 0,303 & 0,1865 \\
0,2794 & 0,378 & 0,303 & 0,2798 \\
0,2794 & 0,2835 & 0,4041 & 0,2798 \\
0,3492 & 0,189 & 0,202 & 0,2798 \\
0,3492 & 0,378 & 0,303 & 0,0933 \\
0,3492 & 0,0945 & 0,303 & 0,4663 \\
0,2794 & 0,378 & 0,303 & 0,373 \\
0,2794 & 0,2835 & 0,4041 & 0,4663 \\
0,3492 & 0,378 & 0,4041 & 0,0933
\end{array}\right]
$$

2. Pembobotan pada matriks yang telah dinormalisasi

$$
\mathrm{R}=\left[\begin{array}{cccc}
0,3492 & 0,2835 & 0,101 & 0,373 \\
0,2794 & 0,378 & 0,303 & 0,1865 \\
0,2794 & 0,378 & 0,303 & 0,2798 \\
0,2794 & 0,2835 & 0,4041 & 0,2798 \\
0,3492 & 0,189 & 0,202 & 0,2798 \\
0,3492 & 0,378 & 0,303 & 0,0933 \\
0,3492 & 0,0945 & 0,303 & 0,4663 \\
0,2794 & 0,378 & 0,303 & 0,373 \\
0,2794 & 0,2835 & 0,4041 & 0,4663 \\
0,3492 & 0,378 & 0,4041 & 0,0933
\end{array}\right] \times\left[\begin{array}{llll}
5 & 2 & 2 & 1
\end{array}\right]
$$

Sehingga diperoleh matriks V :

$$
\mathrm{V}=\left[\begin{array}{cccc}
1,7461 & 0,5669 & 0,202 & 0,373 \\
1,3969 & 0,7559 & 0,6061 & 0,1865 \\
1,3969 & 0,7559 & 0,6061 & 0,2798 \\
1,3969 & 0,5669 & 0,8081 & 0,2798 \\
1,7461 & 0,378 & 0,4041 & 0,2798 \\
1,7461 & 0,7559 & 0,6061 & 0,0933 \\
1,7461 & 0,189 & 0,6061 & 0,4663 \\
1,3969 & 0,7559 & 0,6061 & 0,373 \\
1,3969 & 0,5669 & 0,8081 & 0,4663 \\
1,7461 & 0,7559 & 0,8081 & 0,0933
\end{array}\right]
$$

3. Menentukan himpunan concordance dan disordance index

$$
\begin{aligned}
& \text { Concordance } \\
& \mathrm{C} 12=\{\mathrm{j}, \mathrm{v} 1 \mathrm{j} \geq \mathrm{v} 2 \mathrm{j}\}=\{1,4\} \\
& \mathrm{C} 13=\{\mathrm{j}, \mathrm{v} 1 \mathrm{j} \geq \mathrm{v} 3 \mathrm{j}\}=\{1,4\} \\
& \mathrm{C} 14=\{\mathrm{j}, \mathrm{v} 1 \mathrm{j} \geq \mathrm{v} 4 \mathrm{j}\}=\{1,2,4\} \\
& \mathrm{C} 15=\{\mathrm{j}, \mathrm{v} 1 \mathrm{j} \geq \mathrm{v} 5 \mathrm{j}\}=\{1,2,4\} \\
& \mathrm{C} 16=\{\mathrm{j}, \mathrm{v} 1 \mathrm{j} \geq \mathrm{v} 6 \mathrm{j}\}=\{1,4\}
\end{aligned}
$$

$$
\begin{aligned}
& \text { Discordance } \\
& \text { D12 }=\{\mathrm{j}, \mathrm{v} 1 \mathrm{j}<\mathrm{v} 2 \mathrm{j}\}=\{2,3\} \\
& \mathrm{D} 13=\{\mathrm{j}, \mathrm{v} 1 \mathrm{j}<\mathrm{v} 3 \mathrm{j}\}=\{2,3\} \\
& \mathrm{D} 14=\{\mathrm{j}, \mathrm{v} 1 \mathrm{j}<\mathrm{v} 4 \mathrm{j}\}=\{3\} \\
& \mathrm{D} 15=\{\mathrm{j}, \mathrm{v} 1 \mathrm{j}<\mathrm{v} 5 \mathrm{j}\}=\{3\} \\
& \text { D16 }=\{\mathrm{j}, \mathrm{v} 1 \mathrm{j}<\mathrm{v} 6 \mathrm{j}\}=\{2,3\}
\end{aligned}
$$




\begin{tabular}{|c|c|}
\hline $\mathrm{C} 17=\{\mathrm{j}, \mathrm{v} 1 \mathrm{j} \geq \mathrm{v} 7 \mathrm{j}\}=\{1,2\}$ & $\mathrm{D} 17=\{\mathrm{j}, \mathrm{v} 1 \mathrm{j}<\mathrm{v} 7 \mathrm{j}\}=\{3,4\}$ \\
\hline $\mathrm{C} 18=\{\mathrm{j}, \mathrm{v} 1 \mathrm{j} \geq \mathrm{v} 8 \mathrm{j}\}=\{1,4\}$ & $\mathrm{D} 18=\{\mathrm{j}, \mathrm{v} 1 \mathrm{j}<\mathrm{v} 8 \mathrm{j}\}=\{2,3\}$ \\
\hline $\mathrm{C} 19=\{\mathrm{j}, \mathrm{v} 1 \mathrm{j} \geq \mathrm{v} 9 \mathrm{j}\}=\{1,2\}$ & $\mathrm{D} 19=\{\mathrm{j}, \mathrm{v} 1 \mathrm{j}<\mathrm{v} 9 \mathrm{j}\}=\{3,4\}$ \\
\hline $\mathrm{C} 110=\{\mathrm{j}, \mathrm{v} 1 \mathrm{j} \geq \mathrm{v} 10 \mathrm{j}\}=\{1,4\}$ & $\mathrm{D} 110=\{\mathrm{j}, \mathrm{v} 1 \mathrm{j}<\mathrm{v} 10 \mathrm{j}\}=\{2,3\}$ \\
\hline $\mathrm{C} 21=\{\mathrm{j}, \mathrm{v} 2 \mathrm{j} \geq \mathrm{v} 1 \mathrm{j}\}=\{2,3\}$ & $\mathrm{D} 21=\{\mathrm{j}, \mathrm{v} 2 \mathrm{j}<\mathrm{v} 1 \mathrm{j}\}=\{1,4\}$ \\
\hline $\mathrm{C} 23=\{\mathrm{j}, \mathrm{v} 2 \mathrm{j} \geq \mathrm{v} 3 \mathrm{j}\}=\{1,2,3\}$ & $D 23=\{j, v 2 j<v 3 j\}=\{4\}$ \\
\hline $\mathrm{C} 24=\{\mathrm{j}, \mathrm{v} 2 \mathrm{j} \geq \mathrm{v} 4 \mathrm{j}\}=\{2,3\}$ & $\mathrm{D} 24=\{\mathrm{j}, \mathrm{v} 2 \mathrm{j}<\mathrm{v} 4 \mathrm{j}\}=\{3,4\}$ \\
\hline $\mathrm{C} 25=\{\mathrm{j}, \mathrm{v} 2 \mathrm{j} \geq \mathrm{v} 5 \mathrm{j}\}=\{1,2,4\}$ & $\mathrm{D} 25=\{\mathrm{j}, \mathrm{v} 2 \mathrm{j}<\mathrm{v} 5 \mathrm{j}\}=\{1,4\}$ \\
\hline $\mathrm{C} 26=\{\mathrm{j}, \mathrm{v} 2 \mathrm{j} \geq \mathrm{v} 6 \mathrm{j}\}=\{1,4\}$ & $D 26=\{\mathrm{j}, \mathrm{v} 2 \mathrm{j}<\mathrm{v} 6 \mathrm{j}\}=\{1\}$ \\
\hline $\mathrm{C} 27=\{\mathrm{j}, \mathrm{v} 2 \mathrm{j} \geq \mathrm{v} 7 \mathrm{j}\}=\{1,2\}$ & $\mathrm{D} 27=\{\mathrm{j}, \mathrm{v} 2 \mathrm{j}<\mathrm{v} 7 \mathrm{j}\}=\{1,4\}$ \\
\hline $\mathrm{C} 28=\{\mathrm{j}, \mathrm{v} 2 \mathrm{j} \geq \mathrm{v} 8 \mathrm{j}\}=\{1,4\}$ & $\mathrm{D} 28=\{\mathrm{j}, \mathrm{v} 2 \mathrm{j}<\mathrm{v} 8 \mathrm{j}\}=\{4\}$ \\
\hline $\mathrm{C} 29=\{\mathrm{j}, \mathrm{v} 2 \mathrm{j} \geq \mathrm{v} 9 \mathrm{j}\}=\{1,2\}$ & $\mathrm{D} 29=\{\mathrm{j}, \mathrm{v} 2 \mathrm{j}<\mathrm{v} 9 \mathrm{j}\}=\{3,4\}$ \\
\hline $\mathrm{C} 210=\{\mathrm{j}, \mathrm{v} 2 \mathrm{j} \geq \mathrm{v} 10 \mathrm{j}\}=\{1,4\}$ & $\mathrm{D} 210=\{\mathrm{j}, \mathrm{v} 2 \mathrm{j}<\mathrm{v} 10 \mathrm{j}\}=\{1,3\}$ \\
\hline $\mathrm{C} 71=\{\mathrm{j}, \mathrm{v} 7 \mathrm{j} \geq \mathrm{v} 1 \mathrm{j}\}=\{1,3,4\}$ & $D 71=\{j, v 7 j<v 1 j\}=\{2\}$ \\
\hline $\mathrm{C} 72=\{\mathrm{j}, \mathrm{v} 7 \mathrm{j} \geq \mathrm{v} 2 \mathrm{j}\}=\{1,3,4\}$ & $D 72=\{j, v 7 j<v 2 j\}=\{2\}$ \\
\hline $\mathrm{C} 73=\{\mathrm{j}, \mathrm{v} 7 \mathrm{j} \geq \mathrm{v} 3 \mathrm{j}\}=\{1,3,4\}$ & $D 73=\{j, v 7 j<v 3 j\}=\{2\}$ \\
\hline $\mathrm{C} 74=\{\mathrm{j}, \mathrm{v} 7 \mathrm{j} \geq \mathrm{v} 4 \mathrm{j}\}=\{1,4\}$ & $\mathrm{D} 74=\{\mathrm{j}, \mathrm{v} 7 \mathrm{j}<\mathrm{v} 4 \mathrm{j}\}=\{2,3\}$ \\
\hline $\mathrm{C} 75=\{\mathrm{j}, \mathrm{v} 7 \mathrm{j} \geq \mathrm{v} 5 \mathrm{j}\}=\{1,3,4\}$ & $\mathrm{D} 75=\{\mathrm{j}, \mathrm{v} 7 \mathrm{j}<\mathrm{v} 5 \mathrm{j}\}=\{2\}$ \\
\hline $\mathrm{C} 76=\{\mathrm{j}, \mathrm{v} 7 \mathrm{j} \geq \mathrm{v} 6 \mathrm{j}\}=\{1,3,4\}$ & $D 76=\{\mathrm{j}, \mathrm{v} 7 \mathrm{j}<\mathrm{v} 6 \mathrm{j}\}=\{2\}$ \\
\hline $\mathrm{C} 78=\{\mathrm{j}, \mathrm{v} 7 \mathrm{j} \geq \mathrm{v} 8 \mathrm{j}\}=\{1,3,4\}$ & $\mathrm{D} 78=\{\mathrm{j}, \mathrm{v} 7 \mathrm{j}<\mathrm{v} 8 \mathrm{j}\}=\{2\}$ \\
\hline $\mathrm{C} 79=\{\mathrm{j}, \mathrm{v} 7 \mathrm{j} \geq \mathrm{v} 9 \mathrm{j}\}=\{1,4\}$ & $\mathrm{D} 79=\{\mathrm{j}, \mathrm{v} 7 \mathrm{j}<\mathrm{v} 9 \mathrm{j}\}=\{2,3\}$ \\
\hline$C 710=\{j, v 7 j \geq v 10 j\}=\{1,4\}$ & $D 710=\{j, v 7 j<v 10 j\}=\{2,3\}$ \\
\hline$C 81=\{j, v 8 j \geq v 1 j\}=\{2,3,4\}$ & $\mathrm{D} 81=\{\mathrm{j}, \mathrm{v} 8 \mathrm{j}<\mathrm{v} 1 \mathrm{j}\}=\{1\}$ \\
\hline$C 82=\{j, v 8 j \geq v 2 j\}=\{1,2,3,4\}$ & $\mathrm{D} 82=\{\mathrm{j}, \mathrm{v} 8 \mathrm{j}<\mathrm{v} 2 \mathrm{j}\}=\{\}$ \\
\hline$C 83=\{j, v 8 j \geq v 3 j\}=\{1,2,3,4\}$ & $D 83=\{\mathrm{j}, \mathrm{v} 8 \mathrm{j}<\mathrm{v} 3 \mathrm{j}\}=\{\}$ \\
\hline $\mathrm{C} 84=\{\mathrm{j}, \mathrm{v} 8 \mathrm{j} \geq \mathrm{v} 4 \mathrm{j}\}=\{1,2,4\}$ & $\mathrm{D} 84=\{\mathrm{j}, \mathrm{v} 8 \mathrm{j}<\mathrm{v} 4 \mathrm{j}\}=\{3\}$ \\
\hline $\mathrm{C} 85=\{\mathrm{j}, \mathrm{v} 8 \mathrm{j} \geq \mathrm{v} 5 \mathrm{j}\}=\{2,3,4\}$ & $\mathrm{D} 85=\{\mathrm{j}, \mathrm{v} 8 \mathrm{j}<\mathrm{v} 5 \mathrm{j}\}=\{1\}$ \\
\hline $\mathrm{C} 86=\{\mathrm{j}, \mathrm{v} 8 \mathrm{j} \geq \mathrm{v} 6 \mathrm{j}\}=\{2,3,4\}$ & $\mathrm{D} 86=\{\mathrm{j}, \mathrm{v} 8 \mathrm{j}<\mathrm{v} 6 \mathrm{j}\}=\{1\}$ \\
\hline $\mathrm{C} 87=\{\mathrm{j}, \mathrm{v} 8 \mathrm{j} \geq \mathrm{v} 7 \mathrm{j}\}=\{2,3\}$ & $\mathrm{D} 87=\{\mathrm{j}, \mathrm{v} 8 \mathrm{j}<\mathrm{v} 7 \mathrm{j}\}=\{1,4\}$ \\
\hline $\mathrm{C} 89=\{\mathrm{j}, \mathrm{v} 8 \mathrm{j} \geq \mathrm{v} 9 \mathrm{j}\}=\{1,2\}$ & $\mathrm{D} 89=\{\mathrm{j}, \mathrm{v} 8 \mathrm{j}<\mathrm{v} 9 \mathrm{j}\}=\{3,4\}$ \\
\hline$C 810=\{j, v 8 j \geq v 10 j\}=\{2,4\}$ & $D 810=\{j, v 8 j<v 10 j\}=\{1,3\}$ \\
\hline $\mathrm{C} 91=\{\mathrm{j}, \mathrm{v} 9 \mathrm{j} \geq \mathrm{v} 1 \mathrm{j}\}=\{2,3,4\}$ & $\mathrm{D} 91=\{\mathrm{j}, \mathrm{v} 9 \mathrm{j}<\mathrm{v} 1 \mathrm{j}\}=\{1\}$ \\
\hline $\mathrm{C} 92=\{\mathrm{j}, \mathrm{v} 9 \mathrm{j} \geq \mathrm{v} 2 \mathrm{j}\}=\{1,3,4\}$ & $\mathrm{D} 92=\{\mathrm{j}, \mathrm{v} 9 \mathrm{j}<\mathrm{v} 2 \mathrm{j}\}=\{2\}$ \\
\hline
\end{tabular}

Sehingga didapat himpunan concordance :

$\left[\begin{array}{cccccccccc}- & 1,4 & 1,4 & 1,2,4 & 1,2,4 & 1,4 & 1,2 & 1,4 & 1,2 & 1,4 \\ 2,3 & - & 1,2,3 & 1,2 & 2,3 & 2,3,4 & 2,3 & 1,2,3 & 1,2 & 2,4 \\ 2,3 & 1,2,3,4 & - & 1,2,4 & 2,3,4 & 2,3,4 & 2,3 & 1,2,3 & 1,2 & 2,4 \\ 2,3 & 1,3,4 & 1,3,4 & - & 2,3,4 & 3,4 & 2,3 & 1,3 & 1,2,3 & 3,4 \\ 1,3 & 1,4 & 1,4 & 1,4 & - & 1,4 & 1,2 & 1 & 1 & 1,4 \\ 1,2,3 & 1,2,3 & 1,2,3 & 1,2 & 1,2,3 & - & 1,2,3 & 1,2,3 & 1,2 & 1,2,4 \\ 1,3,4 & 1,3,4 & 1,3,4 & 1,4 & 1,3,4 & 1,3,4 & - & 1,3,4 & 1,4 & 1,4 \\ 2,3,4 & 1,2,3,4 & 1,2,3,4 & 1,2,4 & 2,3,4 & 2,3,4 & 2,3 & - & 1,2 & 2,4 \\ 2,3,4 & 1,3,4 & 1,3,4 & 1,2,3,4 & 2,3,4 & 3,4 & 2,3,4 & 1,3,4 & - & 3,4 \\ 1,2,3 & 1,2,3 & 1,2,3 & 1,2,3 & 1,2,3 & 1,2,3,4 & 1,2,3 & 1,2,3 & 1,2,3 & -\end{array}\right]$


Dan himpunan Discordance:

$$
\left[\begin{array}{cccccccccc}
- & 2,3 & 2,3 & 3 & 3 & 2,3 & 3,4 & 2,3 & 3,4 & 2,3 \\
1,4 & - & 4 & 3,4 & 1,4 & 1 & 1,4 & 4 & 3,4 & 1,3 \\
1,4 & & - & 3 & 1 & 1 & 1,4 & 4 & 3,4 & 1,3 \\
1,4 & 2 & 2 & - & 1 & 1,2 & 1,4 & 2,4 & 4 & 1,2 \\
2,4 & 2,3 & 2,3 & 2,3 & - & 2,3 & 3,4 & 2,3,4 & 2,3,4 & 2,3 \\
4 & 4 & 4 & 3,4 & 4 & - & 4 & 4 & 3,4 & 3 \\
2 & 2 & 2 & 2,3 & 2 & 2 & - & 2 & 2,3 & 2,3 \\
1 & & & 3 & 1 & 1 & 1,4 & - & 3,4 & 1,3 \\
1 & 2 & 2 & & 1 & 1,2 & 1 & 2 & - & 1,2 \\
4 & 4 & 4 & 4 & 4 & 4 & 4 & 4 & 4 & -
\end{array}\right]
$$

2. Menghitung matriks concordance dan discordance

Menghitung matriks concordance

$$
\begin{aligned}
& \mathrm{c} 12=\mathrm{w} 1+\mathrm{w} 4=5+1=6 \\
& \mathrm{c} 13=\mathrm{w} 1+\mathrm{w} 4=5+1=6 \\
& \mathrm{c} 14=\mathrm{w} 1+\mathrm{w} 2+\mathrm{w} 4=5+2+1=8 \\
& \mathrm{c} 15=\mathrm{w} 1+\mathrm{w} 2+\mathrm{w} 4=5+2+1=8 \\
& \mathrm{c} 16=\mathrm{w} 1+\mathrm{w} 4=5+1=6 \\
& \mathrm{c} 17=\mathrm{w} 1+\mathrm{w} 2=5+2=7 \\
& \mathrm{c} 18=\mathrm{w} 1+\mathrm{w} 4=5+1=6 \\
& \mathrm{c} 19=\mathrm{w} 1+\mathrm{w} 2=5+2=7 \\
& \mathrm{c} 110=\mathrm{w} 1+\mathrm{w} 4=5+1=6 \\
& \mathrm{c} 21=\mathrm{w} 2+\mathrm{w} 3=2+2=4 \\
& \mathrm{c} 23=\mathrm{w} 1+\mathrm{w} 2+\mathrm{w} 3=5+2+2=9 \\
& \mathrm{c} 24=\mathrm{w} 1+\mathrm{w} 2=5+2=7 \\
& \mathrm{c} 25=\mathrm{w} 2+\mathrm{w} 3=2+2=4 \\
& \mathrm{c} 26=\mathrm{w} 2+\mathrm{w} 3+\mathrm{w} 4=2+2+1=5 \\
& \mathrm{c} 27=\mathrm{w} 2+\mathrm{w} 3=2+2=4 \\
& \mathrm{c} 28=\mathrm{w} 1+\mathrm{w} 2+\mathrm{w} 3=5+2+2=9 \\
& \mathrm{c} 29=\mathrm{w} 1+\mathrm{w} 2=5+2=7 \\
& \mathrm{c} 210=\mathrm{w} 2+\mathrm{w} 4=2+1=3 \\
& \mathrm{c} 31=\mathrm{w} 2+\mathrm{w} 3=2+2=4 \\
& \mathrm{c} 95=\mathrm{w} 2+\mathrm{w} 3+\mathrm{w} 4=2+2+1=5 \\
& \mathrm{c} 96=\mathrm{w} 3+\mathrm{w} 4=2+1=3 \\
& \mathrm{c} 98=\mathrm{w} 1+\mathrm{w} 3+\mathrm{w} 4=5+2+1=8 \\
& \mathrm{c} 910=\mathrm{w} 3+\mathrm{w} 4=2+1=3
\end{aligned}
$$

Sehingga, matriks concordance nya adalah: 
Jatisi

ISSN 2407-4322

Vol. 8, No. 4, Desember 2021, Hal. 2144-2157

E- ISSN 2503-2933

2152

$=\left[\begin{array}{cccccccccc}- & 6 & 6 & 8 & 8 & 6 & 7 & 6 & 7 & 6 \\ 4 & - & 9 & 7 & 4 & 5 & 4 & 9 & 7 & 3 \\ 4 & 10 & - & 8 & 5 & 5 & 4 & 9 & 7 & 3 \\ 4 & 8 & 8 & - & 5 & 3 & 4 & 7 & 9 & 3 \\ 7 & 6 & 6 & 6 & - & 6 & 7 & 5 & 5 & 6 \\ 9 & 9 & 9 & 7 & 9 & - & 9 & 9 & 7 & 8 \\ 8 & 8 & 8 & 6 & 8 & 8 & - & 8 & 6 & 6 \\ 5 & 10 & 10 & 8 & 5 & 5 & 4 & - & 7 & 3 \\ 5 & 8 & 8 & 10 & 5 & 3 & 5 & 8 & - & 3 \\ 9 & 9 & 9 & 9 & 9 & 10 & 9 & 9 & 9 & -\end{array}\right]$

Matriks disordance yang diperoleh :

$\left[\begin{array}{cccccccccc}- & 1 & 1 & 1 & 1 & 1 & 1 & 1 & 1 & 1 \\ 0,8643 & - & 1 & 1 & 0,9239 & 1 & 0,616 & 1 & 1 & 1 \\ 0,8643 & 0 & - & 1 & 0,9239 & 1 & 0,616 & 1 & 1 & 1 \\ 0,5762 & 0,9354 & 0,9354 & - & 0,8643 & 1 & 0,9239 & 0,9354 & 1 & 1 \\ 0,9354 & 1 & 1 & 1 & - & 1 & 1 & 1 & 1 & 1 \\ 0,6923 & 0,267 & 0,5341 & 0,5785 & 0,4934 & - & 0,6579 & 0,8011 & 1 & 1 \\ 0,9354 & 1 & 1 & 1 & 0,9354 & 1 & - & 1 & 1 & 1 \\ 0,8643 & 0 & 0 & 1 & 0,9239 & 1 & 0,616 & - & 1 & 1 \\ 0,5762 & 0 & 0 & 1 & 0,8643 & 0,9362 & 0,9239 & 0,9354 & - & 0,9362 \\ 0,4616 & 0,267 & 0,5341 & 0,5341 & 0,4616 & 0 & 0,6579 & 0,8011 & 1 & -\end{array}\right]$

4. Menentukan matriks dominan concordance dan discordance

Menghitung matriks dominan concordance

Nilai threshold (c)

$=\frac{608}{90}=6,75$

Menghitung matriks dominan discordance

$=\frac{9,9814}{12}=0,8318$

Sehingga, matriks dominan concordance dan discordance berikut ini.

$$
\mathrm{F}=\left[\begin{array}{cccccccccc}
- & 0 & 0 & 1 & 1 & 0 & 1 & 0 & 1 & 0 \\
0 & - & 1 & 1 & 0 & 0 & 0 & 1 & 1 & 0 \\
0 & 1 & - & 1 & 0 & 0 & 0 & 1 & 1 & 0 \\
0 & 1 & 1 & - & 0 & 0 & 0 & 1 & 1 & 0 \\
1 & 0 & 0 & 0 & - & 0 & 1 & 0 & 0 & 0 \\
1 & 1 & 1 & 1 & 1 & - & 1 & 1 & 1 & 1 \\
1 & 1 & 1 & 0 & 1 & 1 & - & 1 & 0 & 0 \\
0 & 1 & 1 & 1 & 0 & 0 & 0 & - & 1 & 0 \\
0 & 1 & 1 & 1 & 0 & 0 & 0 & 1 & - & 0 \\
1 & 1 & 1 & 1 & 1 & 1 & 1 & 1 & 1 & -
\end{array}\right] \quad \mathrm{G}=\left[\begin{array}{cccccccccc}
- & 1 & 1 & 1 & 1 & 1 & 1 & 1 & 1 & 1 \\
1 & - & 1 & 1 & 1 & 1 & 0 & 1 & 1 & 1 \\
1 & 0 & - & 1 & 1 & 1 & 0 & 1 & 1 & 1 \\
0 & 1 & 1 & - & 1 & 1 & 1 & 1 & 1 & 1 \\
1 & 1 & 1 & 1 & - & 1 & 1 & 1 & 1 & 1 \\
0 & 0 & 0 & 0 & 0 & - & 0 & 0 & 1 & 1 \\
1 & 1 & 1 & 1 & 1 & 1 & - & 1 & 1 & 1 \\
1 & 0 & 0 & 1 & 1 & 1 & 0 & - & 1 & 1 \\
0 & 0 & 1 & 0 & 1 & 1 & 1 & 1 & - & 1 \\
0 & 0 & 0 & 0 & 0 & 0 & 0 & 0 & 1 & -
\end{array}\right]
$$

Pratama, et., al [Penggunaan Metode Elimination ET Choix Traduisant La Realite (ELECTRE) Untuk Menentukan Penerima Beasiswa PPA] 
5. Menentukan aggregate dominance matrix

$$
\begin{aligned}
& \mathrm{E}=\mathrm{F} \times \mathrm{G} \\
& \mathrm{F}=\left[\begin{array}{cccccccccc}
- & 0 & 0 & 1 & 1 & 0 & 1 & 0 & 1 & 0 \\
0 & - & 1 & 1 & 0 & 0 & 0 & 1 & 1 & 0 \\
0 & 1 & - & 1 & 0 & 0 & 0 & 1 & 1 & 0 \\
0 & 1 & 1 & - & 0 & 0 & 0 & 1 & 1 & 0 \\
1 & 0 & 0 & 0 & - & 0 & 1 & 0 & 0 & 0 \\
1 & 1 & 1 & 1 & 1 & - & 1 & 1 & 1 & 1 \\
1 & 1 & 1 & 0 & 1 & 1 & - & 1 & 0 & 0 \\
0 & 1 & 1 & 1 & 0 & 0 & 0 & - & 1 & 0 \\
0 & 1 & 1 & 1 & 0 & 0 & 0 & 1 & - & 0 \\
1 & 1 & 1 & 1 & 1 & 1 & 1 & 1 & 1 & -
\end{array}\right] \times \mathrm{G}=\left[\begin{array}{cccccccccc}
- & 1 & 1 & 1 & 1 & 1 & 1 & 1 & 1 & 1 \\
1 & - & 1 & 1 & 1 & 1 & 0 & 1 & 1 & 1 \\
1 & 0 & - & 1 & 1 & 1 & 0 & 1 & 1 & 1 \\
0 & 1 & 1 & - & 1 & 1 & 1 & 1 & 1 & 1 \\
1 & 1 & 1 & 1 & - & 1 & 1 & 1 & 1 & 1 \\
0 & 0 & 0 & 0 & 0 & - & 0 & 0 & 1 & 1 \\
1 & 1 & 1 & 1 & 1 & 1 & - & 1 & 1 & 1 \\
1 & 0 & 0 & 1 & 1 & 1 & 0 & - & 1 & 1 \\
0 & 0 & 1 & 0 & 1 & 1 & 1 & 1 & - & 1 \\
0 & 0 & 0 & 0 & 0 & 0 & 0 & 0 & 1 & -
\end{array}\right]
\end{aligned}
$$

Sehingga, matriks aggregate dominance adalah

$$
\mathrm{E}=\left[\begin{array}{cccccccccc}
- & 0 & 0 & 1 & 1 & 0 & 1 & 0 & 1 & 0 \\
0 & - & 1 & 1 & 0 & 0 & 0 & 1 & 1 & 0 \\
0 & 0 & - & 1 & 0 & 0 & 0 & 1 & 1 & 0 \\
0 & 1 & 1 & - & 0 & 0 & 0 & 1 & 1 & 0 \\
1 & 0 & 0 & 0 & - & 0 & 1 & 0 & 0 & 0 \\
0 & 0 & 0 & 0 & 0 & - & 0 & 0 & 1 & 1 \\
1 & 1 & 1 & 0 & 1 & 1 & - & 1 & 0 & 0 \\
0 & 0 & 0 & 1 & 0 & 0 & 0 & - & 1 & 0 \\
0 & 0 & 1 & 0 & 0 & 0 & 0 & 1 & - & 0 \\
0 & 0 & 0 & 0 & 0 & 0 & 0 & 0 & 1 & -
\end{array}\right]
$$

6. Eliminasi alternatif yang Less Favourable

Rangking ditentukan berdasar jumlah angka 1 terbanyak, Alternatif dengan nilai 1 paling sedikit dapat dieleminasi. Nilai terbesar didapatkan oleh Alternatif Mhs_007, dengan nilai 1 terbanyak, dengan demikian Mhs_007 terpilih sebagai penerima beasiswa.

Grafik jumlah angka 1 dari matriks aggregate dominance untuk setiap alternatif dapat dilihat pada gambar 2 . 


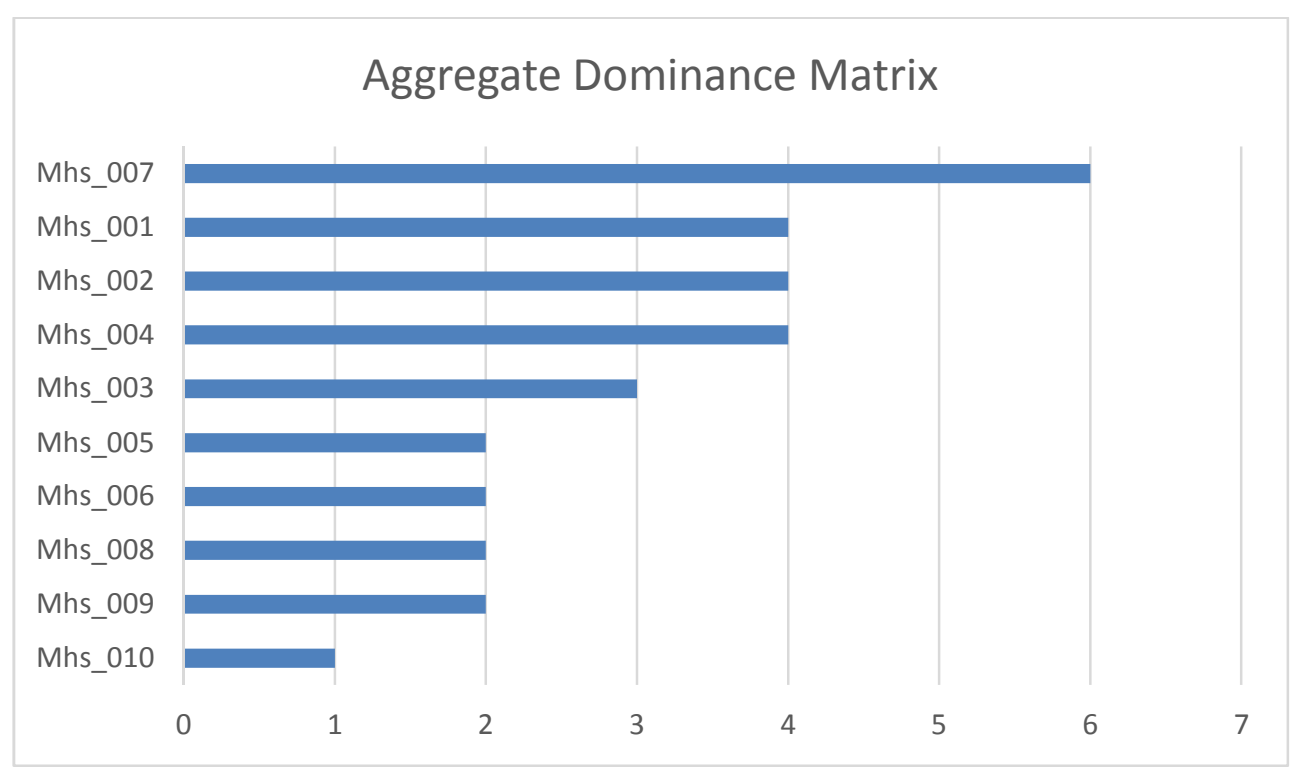

Gambar 2. Grafik Aggregate Dominance Matrix

\section{KESIMPULAN}

Berdasarkan penggunaan metode Elimination Et Choix Traduisant La Realite (ELECTRE) dalam menentukan mahasiswa yang layak sebagai penerima beasiswa peningkatan prestasi akademik pada Fakultas Sains dan Teknologi Universitas Labuhanbatu ini, disimpulkan bahwa proses pemilihan Mahasiswa penerima beasiswa menggunakan beberapa kriteria yang terdiri dari: Indeks Prestasi Mahasiswa, Jumlah Penghasilan Orangtua, Jumlah Tanggungan Orangtua, dan dan jumlah sertifikat prestasi mahasiswa. Melalui penerapan metode Electre ini, pengambilan keputusan oleh pihak fakultas dalam menentukan mahasiswa/i yang layak sebagai penerima beasiswa dapat dilakukan dengan mudah dan tepat. Hasil dari studi kasus pada penelitian ini terpilih sebagai penerima beasiswa diperoleh oleh alternatif Mhs_007 dengan nilai 1 terbanyak, dan alternatif dengan nilai 1 paling sedikit dapat dieliminasi

\section{SARAN}

Untuk pengembangan selanjutnya, disarankan untuk menggunakan metode Elimination Et Choix Traduisant La Realite (ELECTRE) dalam menentukan mahasiswa yang layak sebagai penerima beasiswa peningkatan prestasi akademik pada Fakultas Sains dan Teknologi Universitas Labuhanbatu dengan menggunakan penambahan ataupun penggunaan kriteria lainnya sehingga diperoleh hasil yang lebih baik.

Pratama, et., al [Penggunaan Metode Elimination ET Choix Traduisant La Realite (ELECTRE) Untuk Menentukan Penerima Beasiswa PPA] 


\section{UCAPAN TERIMA KASIH}

Penulis mengucapkan terimakasih kepada Fakultas Sains dan Teknologi Universitas Labuhanbatu yang telah memberi dukungan, bimbingan serta arahan sehingga luaran penelitian ini dapat terpublikasi.

\section{DAFTAR PUSTAKA}

[1] P. Wolo, N. N. Dary, and A. Tai, 2016, "Sistem Pendukung Keputusan Penerimaan Beasiswa Dengan Menggunakan Metode SAW di SDN IV Tubumuri,” Pros. Semin. Nas. Manaj. Teknol. XXV, pp. 7-12.

[2] T. Noviyanti, 2019, "Sistem Penunjang Keputusan Dalam Penerimaan Beasiswa PPA Menggunakan Metode Analytic Hierarchy Process (AHP) (Studi Kasus: Universitas Gunadarma)," J. Ilm. Teknol. dan Rekayasa, Vol. 24, No. 1, pp. 35-45, doi: 10.35760/tr.2019.v24i1.1932.

[3] A. Kusumaningrum Risky Hidayati, Bebas Widada, 2016, "Sistem Pendukung Keputusan Penerimaan Beasiswa Di SMK N 1 Sukoharjo Dengan Metode Simple Additive Weighting (SAW)," J. TIKomSiN, Vol. 4, pp. 14-20, [Online]. Available: https://p3m.sinus.ac.id/jurnal/index.php/TIKomSiN/article/view/240.

[4] Y. Kusnadi and M. W. Dwiyansyah, 2020. "Sistem Pendukung Keputusan Untuk Penerimaan Beasiswa Dengan Metode Simple Additive Weighting (SAW) pada SMKN 1 Ciomas Kabupaten Bogor,” J. Teknol. Inform. dan Komput. MH Thamrin, Vol. 6, No. 1, pp. 120-131.

[5] R. Roni, S. Sumijan, and J. Santony, 2019, "Metode Weighted Product Dalam Pemilihan Penerima Beasiswa Bagi Peserta Didik,” J. RESTI (Rekayasa Sist. dan Teknol. Informasi), Vol. 3, No. 1, pp. 87-93, doi: 10.29207/resti.v3i1.834.

[6] R. I. Borman and F. Helmi, 2018, "Penerapan Metode Perbandingan Eksponensial (MPE) Dalam Sistem Pendukung Keputusan Penerima Beasiswa Siswa Berprestasi pada SMK XYZ,” Vol. 3, No. 1, pp. 17-22,

[7] R. M. Simanjorang, 2018, "Sistem Pendukung Keputusan Penentuan Mahasiswa Lulusan Terbaik Menggunakan Metode Analitycal Hierarchy Process pada Perguruan Tinggi," J. Mantik Penusa, Vol. 2, No. 1, pp. 1-10.

[8] Hilyah Magdalena. 2012, "Sistem Pendukung Keputusan Untuk Menentukan Mahasiswa Lulusan Terbaik Di Perguruan Tinggi (Studi Kasus STMIK Atma Luhur Pangkalpinang)," in Seminar Nasional Teknologi Informasi dan Komunikasi 2012 (SENTIKA 2012) ISSN: 2089-9815, pp. 49-56.

Pratama, et., al [Penggunaan Metode Elimination ET Choix Traduisant La Realite (ELECTRE) Untuk Menentukan Penerima Beasiswa PPA] 
[9] R. Romiyadi, 2016. "Sistem Penunjang Keputusan Penentuan Topik Tugas Akhir Mahasiswa Program Studi Manajemen Informatika (Studi Kasus:Politeknik Muarateweh) Rizar Romiyadi,” J. Bianglala Inform., Vol. 4, No. 1, pp. 1-10,

[10] K. Prayitno and W. Pujiyono, 2014, "Sistem Pendukung Keputusan Dengan Pemetaan Untuk Meningkatkan Ekonomi Berbasis Industri Kecil,” JSTIE (Jurnal Sarj. Tek. Inform., vol. 2, no. 1, pp. 195-206, doi: 10.12928/jstie.v2i1.2617.

[11] O. W. Turangan, C. Kojo, and C. Mintardjo, 2017. "Pengaruh Pemberian Upah Dan Insentif Terhadap Produktivitas Kerja Pegawai Kantor Badan Penanggulangan Bencana Daerah Provinsi Sulawesi Utara,” Vol. 5, No. 2, pp. 3008-3017,

[12] M. Subianto, 2016. "Pengaruh Gaji dan Insentif Terhadap Kinerja Karyawan pada PT. Serba Mulia Auto Di Kabupaten Kutai Barat,” eJournal Adm. Bisnis, Vol. 4, No. 3, pp. 698-712,

[13] H. Wasiati and D. Wijayanti, 2014, "Sistem Pendukung Keputusan Penentuan Kelayakan Calon Tenaga Kerja Indonesia Menggunakan Metode Naive Bayes, ” Wasiati, Hera Wijayanti, Dwi, Vol. 3, No. 2, p. 2,

[14] Ruhul Amin, 2015, "Metode Analytical Hierarchy Process Dalam Sistem Pendukung Keputusan Pemilihan Internet Service Provider,” J. Tek. Komput., Vol. 1, No. 1, pp. 6671 , [Online]. Available: http://ejournal.bsi.ac.id/ejurnal/index.php/jtk/article/view/237/203.

[15] S. Aisyah and W. Purba, 2019, “Aplikasi Sistem Pendukung Keputusan Penilaian Kinerja Karyawan Menggunakan Metode Profile Matching,” J. Mahajana Inf., Vol. 4, No. 2, pp. 16-20,

[16] S. P. Tamba, P. Wulandari, M. Hutabarat, M. Christina, and A. Oktavia, 2019 "Penggunaan Metode Topsis (Technique For Order Preference By Similarity To Ideal Solution) Untuk Menentukan Kualitas Biji Kopi Terbaik Berbasis Android,” J. Mantik Penusa, Vol. 3, No. 1, pp. 73-81,.

[17] J. Simatupang, 2018. "Sistem Pendukung Keputusan Penentuan Karyawan Terbaik Menggunakan Metode SAW Studi Kasus AMIK Mahaputra Riau,” J. Intra-Tech, Vol. 2, No. 1, pp. 73-82,

[18] V. M. M. Siregar, M. R. Tampubolon, E. P. S. Parapat, E. I. Malau, and D. S. Hutagalung, "Decision Support System For Selection Technique Using MOORA Method," IOP Conf. Ser. Mater. Sci. Eng., Vol. 1088, No. 1, p. 012022, Feb. 2021, doi: 10.1088/1757-899X/1088/1/012022.

[19] V. Sihombing, V. M. M. Siregar, W. S. Tampubolon, M. Jannah, Risdalina, and A. Hakim, "Implementation of Simple Additive Weighting Algorithm In Decision Support System," IOP Conf. Ser. Mater. Sci. Eng., Vol. 1088, No. 1, p. 012014, Feb. 2021, doi:

Pratama, et., al [Penggunaan Metode Elimination ET Choix Traduisant La Realite (ELECTRE) Untuk Menentukan Penerima Beasiswa PPA] 
$10.1088 / 1757-899 X / 1088 / 1 / 012014$.

[20] V. M. M. Siregar and H. Sugara, "Implementation of Artificial Neural Network To Assesment The Lecturer'S Performance," IOP Conf. Ser. Mater. Sci. Eng., Vol. 420, p. 012112, Oct. 2018, doi: 10.1088/1757-899X/420/1/012112.

[21] V. M. M. Siregar, S. Sonang, A. T. Purba, H. Sugara, and N. F. Siagian, "Implementation of TOPSIS Algorithm for Selection of Prominent Student Class," J. Phys. Conf. Ser., Vol. 1783, No. 1, p. 012038, Feb. 2021, doi: 10.1088/17426596/1783/1/012038.

[22] B. Satria et al., 2010, "Penerapan Metode Electre Sebagai Sistem Pendukung Keputusan Dalam Penerimaan Beasiswa,” Vol. 3814, pp. 1-6.

[23] A. Wahyu, F. Pradana, and I. F. Rozi, 2015, "SPK Penentuan Beasiswa Siswa Kurang Mampu Dengan Menggunakan Metode Electre (Studi Kasus SMA Negeri 4 Bojonegoro),” Pros. Semin. Inform. Apl. Polinema, Vol. 2015, pp. 122-125.

[24] F. Faidhani and A. S. Sukamto, 2021, "Sistem Pendukung Keputusan Penentu Bidang Keahlian Mahasiswa Program Studi Informatika Universitas Tanjungpura dengan Metode ELECTRE Decision Support System for Determining The Areas of Expertise for Students in The Informatics Study Program At The Univer," Vol. 9, No. 1, pp. 41-47, doi: 10.26418/justin.v9i1.31357.

[25] V. M. M. Siregar et al., "Implementation of ELECTRE Method for Decision Support System,” IOP Conf. Ser. Mater. Sci. Eng., Vol. 1088, No. 1, p. 012027, Feb. 2021, doi: 10.1088/1757-899X/1088/1/012027. 